Research article

\title{
Comprehensive analysis of different adhesives in aerobiological sampling using optical microscopy and high-throughput DNA sequencing
}

\author{
Jesús Rojo ${ }^{\mathrm{a}}$, Andrés Núñez ${ }^{\mathrm{b}}$, Beatriz Lara ${ }^{\mathrm{a}}$, Beatriz Sánchez-Parra ${ }^{\mathrm{b}}$, Diego A. Moreno ${ }^{\mathrm{b}, \mathrm{c}}$, Rosa Pérez-Badia ${ }^{\mathrm{a}, *}$ \\ " Universidad de Castilla-La Maicha, Instinto de Clencias Ambientales (Botonica), Avda Carlos III s/n, E.45071 Toledo, Spain \\ 'Escuela Técrica Superior de Ingenieros Induseriales, Universidad Pobirénica de Madrid (E7SH-UPM), Madrid, Spain \\ 'Universidad de Costilla-La Mancha, Faculad de Famacia, Auda. Dr. José Marla Sánchez s/n, E-02008 Albaceve, Spain
}

\section{A R T I CLE IN F O}

\section{Keywords:}

Aerobiology

Adhesive

Morphological analysis

High-throughput DNA sequencing

Pollen

\begin{abstract}
A B S T R A C T
The standardization and unification of the procedures to analyze and quantify the airbome pollen concentrations are very important topics. In this work, the effectiveness of the two most used adhesives in aerobiological sampling, silicone prepared with cyclohexane solvent (Silicone) and petroleum jelly (Vaseline), was compared under outdoor conditions. This comparison was carried out using the traditional method based on the identification and quantification by optical microscopy (OM) of the airborne pollen and the novel methodolosy by high-throughput sequencing analysis (HTS). Globally, the results from both methods of analysis (OM and HTS) showed a good agreement between the two adhesives tested regarding the abundance of the main pollen types present in the samples: Cupressaceae, Olea, Poaceae, Platanus, Querous. We concluded that the results from both adhesives are comparable data. Furthermore, the comparisons between methodologies, OM vs. HTS, showed that both techniques can accurately identify the most abundant pollen types in the atmosphere for the studied periods, with a good agrement of their relative abundances especially when the airborne pollen diversity is low but showing some divergences as the number of pollen types increases.
\end{abstract}

\section{Introduction}

The relevance of monitoring the airbome pollen concentration in the atmosphere has been widely stated, not only from environmental, ecological and agronomic points of views (Fröhlich Nowoisky et al., 2016; García Mozo, 2011; Oteros et al., 2015; Ziello et al., 2012), but also from a human health perspective since the allergenic pollen re present the most important cause of pollinosis around the world (Bonofiglio et al., 2013; Marchetti et al., 2017).

Traditionally, the airbome pollen concentrations are estimated from analyses based on the identification and quantification by optical mi croscopy (Galán et al., 2007). However, the classification of the pollen types at species level employing this procedure is limited because the morphological features of the pollen grains used for their recognition are frequently shared within genera, families and even taxonomical orders. Lately, pollen identification using molecular sequencing and DNA analysis has been proposed as an alternative approach (Leontidou et al., 2018), although it has not been implemented in the daily routine yet.

Debates about the different devices for pollen sampling and the protocols for subsequent determination and analysis of airbome pollen samples have been carried out over the years (Aylor, 1993; Cariñanos et al., 2000; Cotos Yáñez et al., 2013; Gharbi et al., 2017; Levetin et al., 2000; Mullins and Emberlin, 1997). The interest to achieve a standar dization in order to accurately compare the results from different air borne pollen stations and monitoring networks is a common concern at national (Galán et al., 2007; Oteros et al., 2013; UNI, 2004) and in ternational scale, with the implication of the International Association for Aerobiology (IAA) and also the European Aeroallergen Network and the European Society of Aerobiology (EAS) (Galán et al., 2014; Šikoparija et al., 2017).

In this context, the Hirst volumetric spore traps have been used for more than two decades as a standard device for sampling the airborne pollen by the aerobiological monitoring networks (CEN/TS 16868, 2017; Galán et al., 2014; Jäger et al., 1995; Oteros et al., 2013). Re cently, the use of this equipment has been extended to DNA analysis for the identification of pollen (Kraaijeveld et al., 2015; Leontidou et al., 2018) but also for fungi and bacteria (Núñez et al., 2017). This analysis provides a more accurate taxonomic classification for the cryptic spe cies, reveals new diversity and makes it possible to employ this device

\footnotetext{
- Corresponding author. Avda. Carlos III s/n, E-45071, Toledo, Spain.

E-mail address: rosa.perez@uclm.es (R. Pérez-Badia).
} 
for studying airborne prokaryotes as well.

In the Hirst type spore traps, the particles are collected on an ad hesive surface covering a tape, usually a Melinex ${ }^{\circledR}$ type (Oteros et al., 2015; Rojo et al., 2016). The adhesive employed (cedar oil, paraffin, petroleum jelly vaseline ${ }^{\circ}$, silicone fluid) is also subject of discussion (Alcázar et al., 2003; Alcázar and Comtois, 1999; Galán and Domínguez Vilches, 1997; Hogan, 1971; Käpylä, 1989; Razmovski et al., 1998). Currently, the debate remains because one of the most popular adhesives, the silicone fluid, uses carbon tetrachloride as sol vent during the preparation, which is considered toxic (Manibusan et al., 2007; Willis and Keller, 2007). In this sense, Maya Manzano et al. (2018) compared and proposed the use of petroleum jelly (Vaseline) as a substitute for silicone fluid prepared with the carbon tetrachloride (Silicone) to avoid the use of hazardous compounds. Before, some au thors such as Thibaudon et al. (2015) proposed the use of diethyl ether as an alternative to carbon tetrachloride. However, the diethyl ether is not free of toxicity (Pohanish, 2017), so Gharbi et al. (2019) tested the use of cyclohexane and they concluded, as other studies demonstrated in other fields (Furuse et al., 2001), that could be recommended as the alternative to carbon tetrachloride.

With this background, here we compared the effectiveness of the two adhesives most frequently employed currently in the airborne pollen monitoring networks: the petroleum jelly or Vaseline (Warner et al., 2000) and silicone fluid (Oteros et al., 2013) prepared with the cyclohexane solvent. We analyzed samples collected at different sea sons and studied the differences by optical microscopy (OM) of the most abundant pollen types under non controlled conditions. Moreover, we evaluated the application of both adhesives for high throughput se quencing (HTS) analyses and also compared the results obtained from both methodologies (OM and HTS).

\section{Methods}

\subsection{Sampling methodology}

Two Hirst type volumetric spore traps (Burkard Manufacturing Co., UK) (Hirst, 1952) were placed on the roof of the building "Escuela Técnica Superior de Ingenieros Industriales, Universidad Politécnica de Madrid" (Madrid, Spain, $40.439881^{\circ}$ N, $3.689409^{\circ} \mathrm{W}, 21 \mathrm{~m}$ AGL, $705 \mathrm{~m}$ AMSL), with a $2 \mathrm{~m}$ separation. All the material to be in contact with the samples was sterilized in advance and further steps of manipulation were performed in a Telstar AV 100 biosafety cabinet, with the use of sterile gloves to prevent DNA contamination. The Melinex tapes were cut longitudinally into two equal parts, attached to the drums and covered with either vaseline (pharmaceutical sterile petroleum jelly; Interapothek), hereinafter Vaseline, or silicone solution with cyclo hexane solvent, hereinafter Silicone. Next, one half of each Melinex tape was withdrawn and placed in a new drum in combination with another half covered with a different adherent substance, resulting in two identical drums with half tape covered with Vaseline and the other half with Silicone (as proposed by Käpylä, 1989). Each drum was placed in one of the spore traps and ran synchronously, collecting four in dependent 7 days samples (see Table 1 for additional information). Airflow was checked before and after sampling to verify that the flow rate $(\sim 10 \mathrm{~L} / \mathrm{min})$ was constant across the time period and between devices. The same handheld rotameter was used for calibrating the both devices, avoiding errors due to the different flow rate (Oteros et al., 2017).

\subsection{Morphological analysis using optical microscopy}

The methodological criteria followed for aerobiological sampling and morphological analysis of the samples follows the recommenda tions of the International Association for Aerobiology (IAA) and the Spanish Network of Aerobiology (REA) (Galán et al., 2007). Morpho logical analysis of the samples was carried out by identification and quantification for the airborne pollen types using optical microscopy ( $\times 400$ magnification). Daily and bi hourly pollen concentrations were estimated with three longitudinal sweeps per slide (for each half of each Melinex tape), therefore analyzing a larger surface of the tape than the minimum representative area proposed by the standards (Galán et al., 2007; Gharbi et al., 2017). Results were expressed as number of pollen grains per cubic meter of air (grains $/ \mathrm{m}^{3}$ ).

\subsection{DNA extraction and quantitation}

One drum from each sampling was used for DNA analysis. After sampling, the Vaseline or Silicone of the Melinex tape with the particles adhered was collected in the biosafety cabinet by using a sterilized razor and placed it directly into a lysis tube of the DNA extraction kit (DNeasy PowerSoil Kit, QIAGEN). DNA was extracted following the manufacturer's instructions, eluted in a final volume of $60 \mu \mathrm{L}$ and quantified with a Quant iT PicoGreen double stranded DNA (dsDNA) assay kit (Invitrogen, Molecular Probes) using a QuantiFluor Fluorometer (Promega). High throughput sequencing analyses were performed using the purified DNA from each sample. An additional negative control was set as a 7 days sample keeping the vacuum of the sampler off.

\subsection{High throughput sequencing}

Three of the four samples collected (Table 1) were subjected to high throughput sequencing at "Parque Científico de Madrid" (Madrid, Spain). Specific regions from 5.8S ITS2 of plants were amplified with the primers set ITS p3 (F): 5' YGACTCTCGGCAACGGATA 3' (Cheng et al., 2016), and ITS 4 (R): 5' TCCTCCGCTTATTGATATGC 3' (White et al., 1990). The amplicons ( $\sim 410 \mathrm{bp}$ ) were attached to adaptors and multiplex identifier sequences for the preparation of the DNA library (conditions: $30 \mathrm{~s}$ at $98^{\circ} \mathrm{C} ; 20$ cycles of the following steps: $10 \mathrm{~s}$ at $98^{\circ} \mathrm{C}$; $20 \mathrm{~s}$ at $50{ }^{\circ} \mathrm{C}$; $20 \mathrm{~s}$ at $72{ }^{\circ} \mathrm{C}$; and a final step of $2 \mathrm{~min}$ at $72{ }^{\circ} \mathrm{C}$ ). The ne gative control sample did not retrieve any PCR product during the preparation of the library following the same conditions, although it was included in the sequencing batch. The amplicon libraries were purified with Agencourt AMPure XP (Beckman Coulter) and sequenced using Illumina MiSeq platform $(2 \times 300$ bp reads). Raw sequence data obtained in this study are available in the National Center for Bio technology Information (NCBI), BioProject PRJNA522959 (Accession no. SRR8601809 SRR8601814).

\section{Table 1}

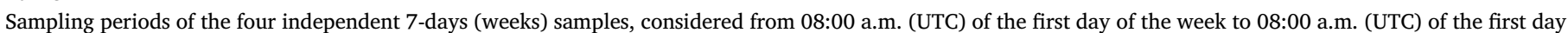

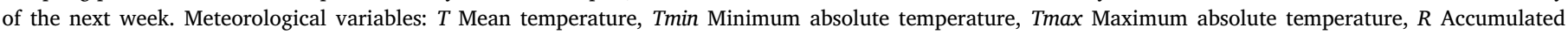
rainfall. Analysis: OM Morphological analysis by optical microscopy, HTS High-Throughput Sequencing.

\begin{tabular}{|c|c|c|c|c|c|}
\hline Sample & Period & Most abundant pollen types detected ( $>5 \%$ of abundance for each week) & $\mathrm{T}^{\circ} \mathrm{C}$ (Tmin, Tmax) & $\mathrm{R}(\mathrm{mm})$ & Analysis \\
\hline Week 1 & $22^{\text {nd }}-29^{\text {th }}$ June 2016 & Olea, Pinus, Poaceae, Quercus & $27.0(17.2-35.8)$ & 0 & OM/HTS \\
\hline Week 2 & $14^{\text {th }}-21^{\text {st }}$ March 2017 & Platanus & $14.7(13.9-24.2)$ & 0 & OM/HTS \\
\hline Week 3 & $22^{\text {nd }}-29^{\text {th }}$ May 2017 & Olea, Pinus, Poaceae, Quercus & $24.6(13.9-33.7)$ & 0 & $\mathrm{OM} / \mathrm{HTS}$ \\
\hline Week 4 & $06^{\text {th }}-13^{\text {th }}$ February 2017 & Cupressaceae & $7.4(1.0-15.9)$ & 32.2 & $\mathrm{OM}$ \\
\hline
\end{tabular}


Table 2

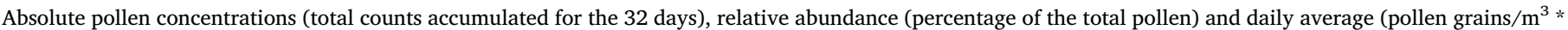
day) for both adhesives (Silicone and Vaseline).

\begin{tabular}{|c|c|c|c|c|c|c|}
\hline \multirow{2}{*}{$\begin{array}{l}\text { Adhesive } \\
\text { Pollen type }\end{array}$} & \multicolumn{3}{|l|}{ Silicone } & \multicolumn{3}{|l|}{ Vaseline } \\
\hline & Total Pollen Counts & Percentage of the total & $\begin{array}{l}\text { pollen grains } / \mathrm{m}^{3} * \\
\text { day }\end{array}$ & Total Pollen Counts & Percentage of the total & pollen grains $/ \mathrm{m}^{3} *$ day \\
\hline Platanus & 1857 & 36.5 & 58.0 & 1859 & 36.7 & 58.1 \\
\hline Olea & 794 & 15.6 & 24.8 & 781 & 15.4 & 24.4 \\
\hline Cupressaceae & 585 & 11.5 & 18.3 & 587 & 11.6 & 18.3 \\
\hline Quercus & 558 & 11.0 & 17.4 & 550 & 10.9 & 17.2 \\
\hline Poaceae & 377 & 7.4 & 11.8 & 434 & 8.6 & 13.6 \\
\hline Pinus & 263 & 5.2 & 8.2 & 209 & 4.1 & 6.5 \\
\hline Populus & 99 & 1.9 & 3.1 & 87 & 1.7 & 2.7 \\
\hline Plantago & 86 & 1.7 & 2.7 & 87 & 1.7 & 2.7 \\
\hline Fraxinus & 72 & 1.4 & 2.2 & 70 & 1.4 & 2.2 \\
\hline Urticaceae & 39 & 0.8 & 1.2 & 42 & 0.8 & 1.3 \\
\hline Ulmus & 31 & 0.6 & 1.0 & 45 & 0.9 & 1.4 \\
\hline Chenopodiaceae/Amaranthaceae & 29 & 0.6 & 0.9 & 31 & 0.6 & 1.0 \\
\hline Acer & 28 & 0.6 & 0.9 & 30 & 0.6 & 0.9 \\
\hline Compositae & 22 & 0.4 & 0.7 & 37 & 0.7 & 1.2 \\
\hline Rumex & 22 & 0.4 & 0.7 & 20 & 0.4 & 0.6 \\
\hline Morus & 14 & 0.3 & 0.4 & 11 & 0.2 & 0.3 \\
\hline Cyperaceae & 11 & 0.2 & 0.3 & 18 & 0.4 & 0.6 \\
\hline Alnus & 8 & 0.2 & 0.2 & 10 & 0.2 & 0.3 \\
\hline Apiaceae & 6 & 0.1 & 0.2 & 7 & 0.1 & 0.2 \\
\hline Other & 180 & 3.5 & & 148 & 2.9 & \\
\hline Total & 5081 & 100.0 & & 5063 & 100.0 & \\
\hline
\end{tabular}

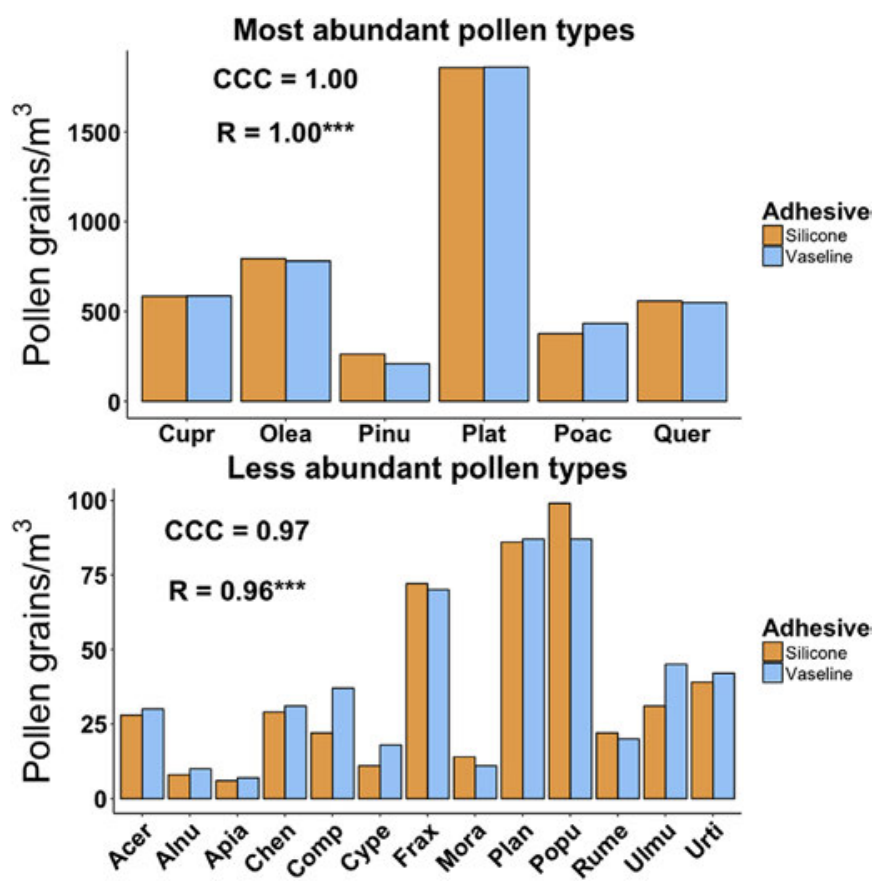

Fig. 1. Differences in absolute pollen concentrations (total counts for the 32 days) between adhesives (Silicone vs. Vaseline). Pollen types: Acer, Alnu Alnus, Apia Apiaceae, Chen Chenopodiaceae/Amaranthaceae, Comp Compositae, Cupr Cupressaceae, Cype Cyperaceae, Frax Fraxinus, Mora Moraceae, Olea, Pinu Pinus, Plan Plantago, Plat Platanus, Poac Poaceae, Popu Populus, Quer Quercus, Rume Rumex, Ulmu Ulmus, Urti Urticaceae. CCC: Lin's Concordance Correlation Coefficient, R: Spearman Correlation Test. Significance levels: ${ }^{*} P<0.05$; $* * P<0.01 ; * * * P<0.001$.

\subsection{Sequence assembly, preprocessing and data analysis}

Bioinformatic processing of HTS data were performed as described in Núñez et al. (2017). Briefly, FastQC software (version 0.11.3, Bab raham Bioinformatics Group, Babraham Institute, UK [www. bioinformatics.babraham.ac.uk/projects/fastqc/]) was employed for general checking; PANDAseq (Masella et al., 2012) (version 2.8, https://github.com/neufeld/pandaseq/wiki/PANDAseq Assembler) was used for quality filtration ( $Q$ score: 0.6 ), paring the sequences and removing those that exceeded the length of the amplicon (min: 320, max: 550). Chimeras were subtracted using USEARCH v8.1 (https:// drive5.com/usearch/) with default values. Global processing was per formed in Qiime suite environment (Caporaso et al., 2010) (version 1.9.1, http://qiime.org) with the default algorithm (pick open refence otus.py) and UCLUST as method for picking OTUs ( $97 \%$ sequence similarity). Taxonomic assignments were performed using UCLUST (minimum consensus: 0.51 , similarity > 0.9, max accepts: 3 ) against a customized database previously described in Núñez et al. (2017).

The data analysis was performed in $\mathrm{R}$ software environment ( $\mathrm{R}$ Development Core Team, 2017) (http://www.R project.org), using the package "phyloseq" (McMurdie and Holmes, 2013) version 1.20.0. We normalized the sequencing depths between samples employing the package "metagenomeSeq" (version 1.18.0, (Paulson et al., 2013), http://cbcb.umd.edu/software/metagenomeSeq). Additional informa tion about sequence processing can be found in Fig. S1 and Table S1 (Supplementary Material). OTUs assigned to fungi or "Unidentified" were removed. Each unique taxonomic assignment was considered a phylotype, independently of the taxonomic level. The correspondence between taxonomic assignments and pollen types was conducted to compare the relative abundance of both values.

\subsection{Statistical analyses}

The statistical analyses were performed with different packages in $\mathrm{R}$ environment ( $\mathrm{R}$ Development Core Team, 2017). The Concordance Correlation Coefficient (CCC) described by Lin (1989) was used to evaluate the agreement between different methods, implemented in the package "epiR" (Stevenson et al., 2017) (function "epi.ccc" with a confidence level at 95\%). The scale of agreement for the test inter pretation was set as follows McBride (2005): almost perfect $(>0.99)$, substantial (0.99 0.95), moderate (0.95 0.90), and poor $(<0.90)$. This agreement index was used to test the concordance of the impaction efficiency of both adhesives (Silicone vs. Vaseline) and to compare the results from morphological identification and HTS. Also, Spearman 

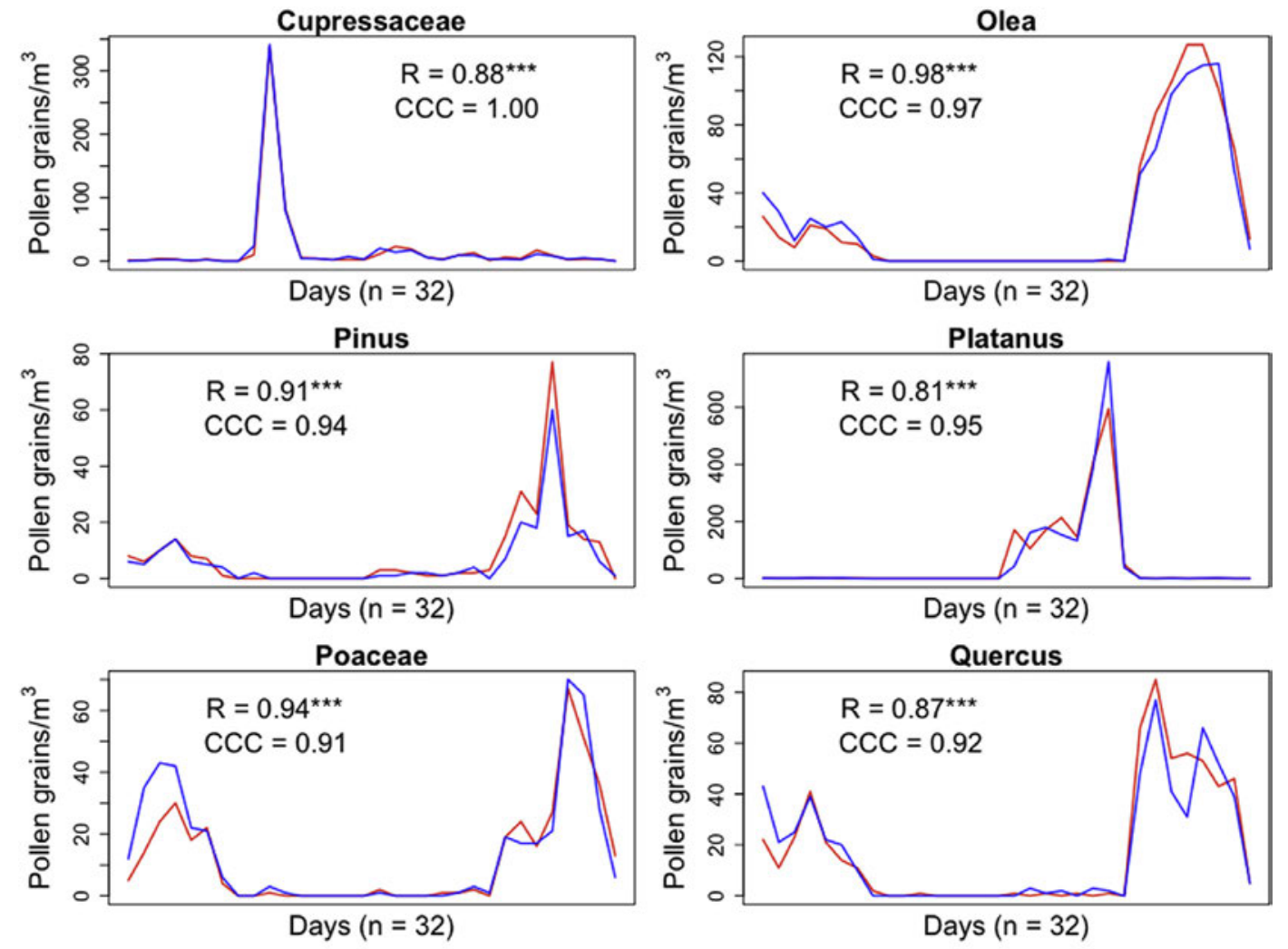

Total

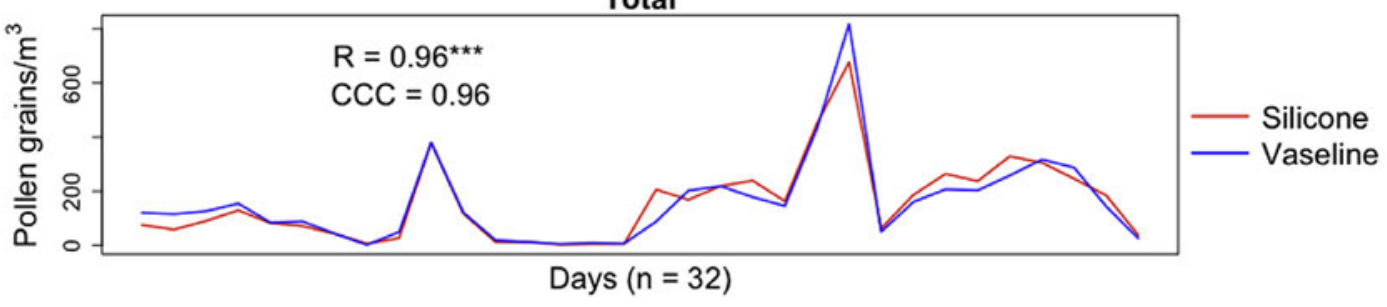

Fig. 2. Differences in daily pollen concentrations between adhesives (Silicone vs. Vaseline) for the most abundant pollen types. CCC: Lin's Concordance Correlation Coefficient, R: Spearman Correlation Test. Significance levels: ${ }^{*} P<0.05 ;{ }^{* *} P<0.01 ;{ }^{* * *} P<0.001$.

Correlation test was applied to compare the correlation between ad hesives for the daily and hourly time series data.

Linear regression models allowed assessing the comparison of the daily pollen concentrations recorded in different adhesive substances in relation to the ideal linear fit (slope $=1$, i.e. the pollen concentrations recorded in Silicone was equal to the pollen concentrations recorded in Vaseline). Finally, due to the character of the data from HTS analysis, the comparison between adhesives (Silicone vs. Vaseline) should be conducted calculating the relative abundance of the OTUs for each week. A similar estimation of the relative abundance was made from the morphological identification (OM) to compare additionally both analysis methods (OM vs. HTS). As sequencing offered a more detailed taxonomic resolution, the OM system was adopted, summing up all the taxa identified by DNA sequencing corresponding to those at a lower taxonomic rank than OM can confirm. See total taxa information in Tables S2 S4 (Supplementary Material).

\section{Results}

3.1. Analysis of the concordance between adhesives for morphological identification (optical microscopy)

To assess the agreement on the airborne pollen collection between both adhesives, Silicone and Vaseline, we firstly evaluated the concordance regarding the absolute pollen concentration. The most abundant pollen types (relative abundance $>5 \%$ for the whole period studied) were Platanus, Olea, Cupressaceae, Quercus, Poaceae and Pinus (Table 2), representing $87.3 \%$ of the total pollen counts accumulated during the four weeks. As shown in Fig. 1, the Lin's Concordance Cor relation Coefficient (CCC) retrieved a value of 1.00 (almost perfect concordance according to McBride's scale (McBride, 2005)), when these pollen types were considered. The concordance was slightly less (CCC $=0.97$, substantial agreement) when the less abundant pollen types were taken into account (relative abundance $<5 \%$ ).

Next, we compared the collection efficiency analyzing the daily pollen concentrations. In the case of the most abundant pollen types, the global analysis showed a substantial correspondence between the pollen concentrations obtained from both adhesives (CCC $=0.96$, Fig. 2, bottom panel) with a remarked good Spearman's correlation value $(R=0.96, P<0.001)$. Nonetheless, different grades of agree ment were calculated when the pollen types were analyzed in dividually, ranging from almost perfect (Cupressaceae, CCC $=1.00$ ) to moderate concordance (Olea and Platanus, CCC $\geq 0.95$; Pinus, Poaceae and Quercus, CCC $\geq 0.90$ ) (Fig. 2). These results were also supported by good values from correlation tests $(R \geq 0.81, P<0.05)$.

Additionally, we performed linear regression analyses to test the divergence of the collection between the adhesives (Fig. 3). In ac cordance with the results exposed above, the pollen of Cupressaceae 
a
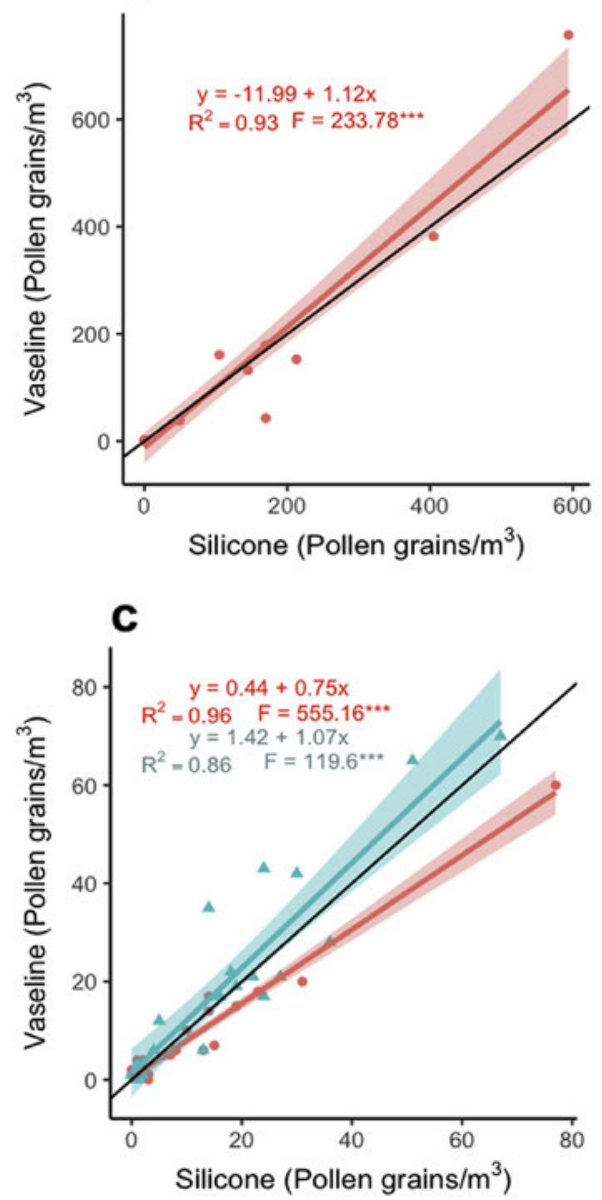

b

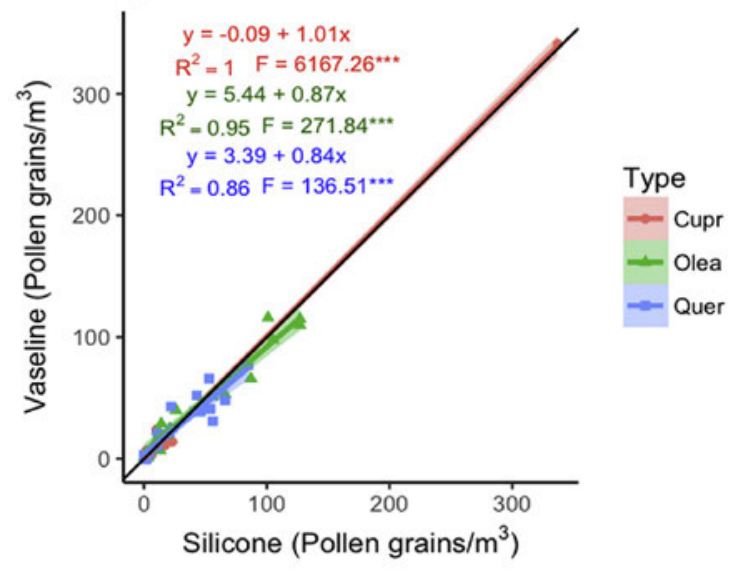

d

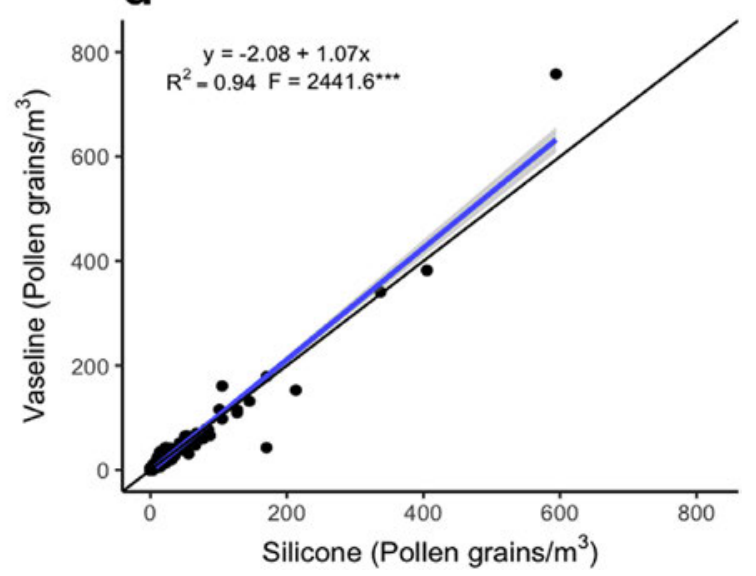

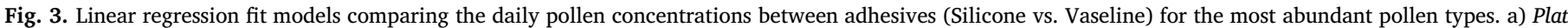

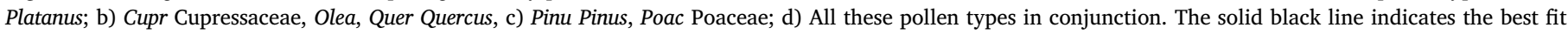
(intercept $=0$ and slope $=1$, ideal case with Silicone $=$ Vaseline). Confidence interval estimation $95 \%$.

showed a well fitted model (slope $=1.01, R^{2}=0.996$ ). Other pollen types with regression slope close to the ideal fit were Platanus, Olea, Quercus and Poaceae (slope between 1.12 and 0.84). Among the most abundant pollen types, Pinus showed the most distant model (slope $=0.75$ ), i.e. Pinus pollen is collected with higher concentrations when Silicone is employed. Regression linear fit displayed a good ad justment between adhesives when daily pollen concentrations for all the most abundant pollen types in conjunction were considered (slope $=1.07, R^{2}=0.94$ ).

Further, we studied the pollen concentration between the adhesives at a bi hourly time scale seeking for a more thorough analysis. The results showed that the pollen concentrations from Silicone were sig nificantly correlated with those from Vaseline when all the pollen types were considered (Fig. 4, bottom panel). Individually, the highest Spearman's correlation coefficient was obtained for Olea pollen ( $R=0.86, P<0.001$ ), while Platanus showed the lowest score $(R=0.50, P<0.001)$. The correlation coefficients were markedly lower than those from a daily time scale (Fig. 2), and coinciding with low CCC values $(<0.90$, poor agreement), suggesting a weaker con cordance between adhesives when bi hourly data are analyzed.

\subsection{Analysis of the concordance between adhesives for HTS data}

Similar to the results for morphological analysis, we studied the concordance of HTS results derived from the different collection (Silicone or Vaseline). As shown in Fig. 5 (upper panel), the analysis of three weeks examined independently revealed that the number of OTUs observed or phylotypes detected were not statistically affected by the adhesives employed during the collection ( $P>0.05$ for $t$ test analysis), and being the variability between periods clearly higher than between the type of collecting surfaces (Supplementary Material Fig. S2). Studying each week individually (Fig. 5, bottom panel), the common OTUs gathered $44.655 .0 \%$ of the total OTUs, although those re presented $>94.1 \%$ of the total abundance, suggesting that those non common OTUs represented a dispensable fraction. In agreement, the number of common phylotypes ranged between 45.9 and $66.1 \%$, compiling $98.599 .9 \%$ of the total abundance, so the contribution of those non common OTUs/phylotypes was clearly minor in both ad hesives. Additionally, CCC values for the distributions of the relative abundances of the OTUs were high $(\geq 0.90)$, confirming that the col lection by the two methods are quite similar for both diversity and abundance perspectives. Only the sampling from Week 3 showed more divergence, likely because a short sequencing depth (see Fig. S1 in Supplementary Material).

Next, we analyzed the effect on the most abundant pollen types. As shown in Table 3, when the data were analyzed as a whole, only the Pinus pollen type retrieved CCC values $<0.90$, which would suggest a remarked difference in the collection for this pollen type, in agreement with the morphological analysis (Fig. 3). For the rest of the pollen types, CCC values showed moderate or good correspondence between both adhesives (CCC $>0.90$, Table 3). Only 4 isolated cases from Olea, Pinus, Plantago and Poaceae retrieved CCC values $<0.90$ when the three weeks were analyzed individually. 

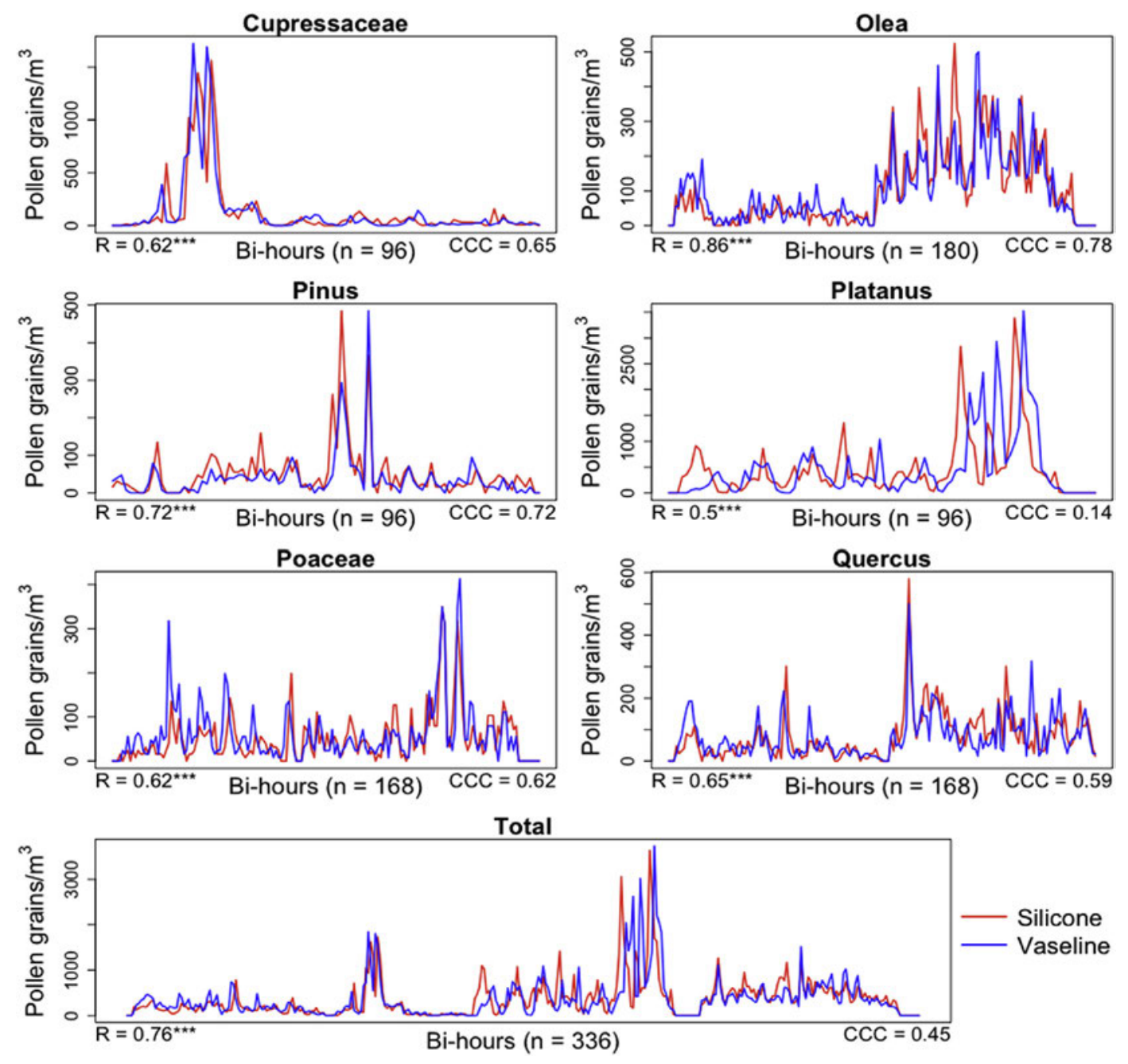

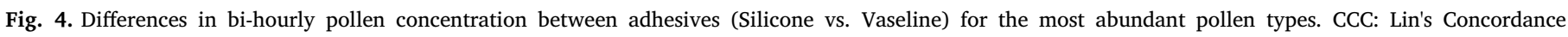
Correlation Coefficient, R: Spearman Correlation Test. Significance level: ${ }^{* * *} P<0.001$.

\subsection{Comparison optical microscopy (OM) vs. high throughput sequencing (HTS)}

As an additional analysis, we studied the concordance between OM and HTS results. Although, globally, the order of the most abundant pollen types according to their relative abundances is similar in both methods (Fig. 6), in some cases such as Olea, Poaceae and Quercus, did not always keep enough correspondence, resulting in low CCC values (Table 4). When all the pollen types are taken into consideration the tests retrieved an excellent concordance ( $\mathrm{CCC}=1.00$ ) between the different analysis methods for Week 2 (March 2017) (Table 4), but a weak concordance (CCC $\leq$ 0.90) for the other two weeks (June 2016, and May 2017). Although these comparisons between HTS and OM may be impaired by several factors (see Discussion), the analyses retrieved always CCC values $>0.98$ (except Week 3 for HTS) when the results from both adhesives using the same methodology, OM or HTS, are compared (Table 4).

\section{Discussion}

In general terms, the results from the morphological analysis (using identification and quantification by optical microscopy, OM) showed a good agreement between the both adhesives analyzed, especially for the most abundant pollen types. Therefore, we concluded that Vaseline and Silicone could be used for aerobiological sampling indistinctly for OM surveys. Regarding molecular methods, HTS showed very concordant results between Silicone and Vaseline. In fact, the results for common and non common OTUs/phylotypes were very similar to those obtained when two independent traps with the same adhesive are tested (Núñez et al., 2017), which supports that the employment of any of these two adhesives are suitable for pollen studies based on DNA. The results obtained from sequencing data also suggested that both ad hesives work equally for HTS analyses in matter of detecting global diversity and for particular analyses by pollen types as well.

Our study has tried to isolate the differences due exclusively to the effect of the adhesive, avoiding as much as possible to include other sources of error (Oteros et al., 2013). Among the cautions taken to minimize as much as possible the adhesive independent sources of error, unlike other works, we assayed both adhesives placed in the same drum inside the volumetric spore trap as proposed by Käpylä (1989). The staff involved in the different phases of the study (i.e. sample preparation, molecular analysis, pollen identification and quantifica tion) was the same, avoiding false differences caused by technician errors (Oteros et al., 2013). Furthermore, the spore traps were cali brated at the beginning and at the end of the four periods of sampling with the same handheld rotameter, assuring a constant flow rate of $10 \mathrm{~L} / \mathrm{min}$ (Oteros et al., 2017) because different flow rates can produce variations over the impaction efficiency of the adhesives regarding the size of the pollen grains (Razmovski et al., 1998). Assuming that all these sources of random error are covered, the differences on pollen concentrations can be attributed to the pollen capture media when the deviation occurs predominantly in only one direction (bias), i.e. the 

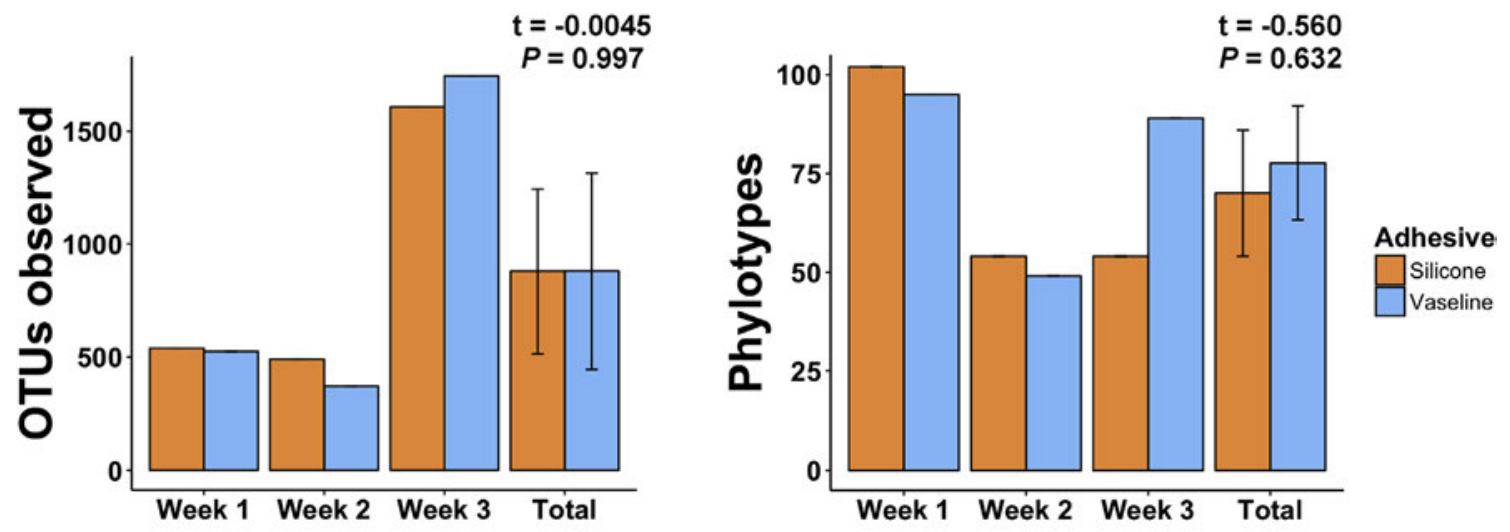

\begin{tabular}{|c|c|c|c|c|c|c|c|c|}
\hline Week & Adhesive & $\begin{array}{c}\text { No. Unique } \\
\text { OTUs/ } \\
\text { phylotypes }\end{array}$ & $\begin{array}{l}\text { OTUs / } \\
\text { phylotypes } \\
\text { in common }\end{array}$ & $\begin{array}{l}\mathrm{RA}^{*} \text { of the OTUs / } \\
\text { phylotypes } \\
\text { in common }\end{array}$ & $\begin{array}{l}\text { No. OTUs / } \\
\text { phylotypes }\end{array}$ & $\begin{array}{l}\text { OTUs/phylotypes } \\
\text { non-common }\end{array}$ & $\begin{array}{l}\mathrm{RA}^{*} \text { of the OTUs/ } \\
\text { phylotypes } \\
\text { non-common }\end{array}$ & $\mathrm{CCC}$ \\
\hline \multirow{2}{*}{1} & Silicone & \multirow{2}{*}{$712 / 120$} & \multirow{2}{*}{$\begin{array}{c}352(49.3 \%) / \\
77(64.2 \%)\end{array}$} & $96.0 \% / 98.9 \%$ & $539 / 25$ & $187(26.3 \%) / 25(20.8 \%)$ & $4.0 \% / 1.1 \%$ & \multirow{2}{*}{0.93} \\
\hline & Vaseline & & & $96.2 \% / 98.5 \%$ & $524 / 18$ & $173(24.3 \%) / 18(15.0 \%)$ & $3.8 \% / 1.5 \%$ & \\
\hline \multirow[b]{2}{*}{2} & Silicone & \multirow{2}{*}{$594 / 62$} & \multirow{2}{*}{$\begin{array}{c}265(44.6 \%) / \\
41(66.1 \%)\end{array}$} & $99.1 \% / 99.9 \%$ & $490 / 13$ & $225(37.9 \%) / 13(21.0 \%)$ & $0.9 \% / 0.1 \%$ & \multirow{2}{*}{0.99} \\
\hline & Vaseline & & & $96.6 \% / 99.9 \%$ & $369 / 8$ & $104 / 17.5 \%) / 8(12.9 \%)$ & $0.4 \% / 0.1 \%$ & \\
\hline & Silicone & \multirow{2}{*}{$2164 / 98$} & $1190(55.0 \%) /$ & $96.0 \% / 98.9 \%$ & $1609 / 9$ & $419(19.4 \%) / 9(9.2 \%)$ & $4.0 \% / 1.1 \%$ & \multirow{2}{*}{0.90} \\
\hline & Vaseline & & $45(45.9 \%)$ & $94.1 \% / 98.2 \%$ & $1745 / 44$ & $555(25.6 \%) / 44(44.9 \%)$ & $5.9 \% / 1.8 \%$ & \\
\hline
\end{tabular}

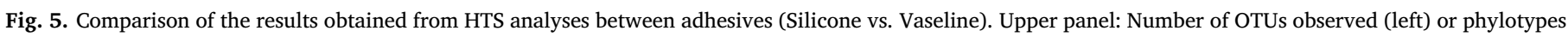

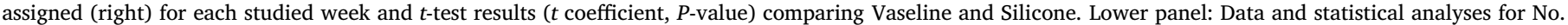

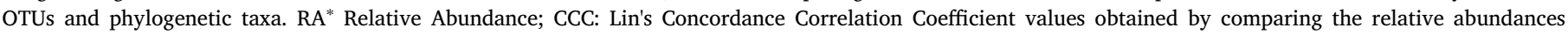
assigned to each OTUs in each collection method.

Table 3

Concordance correlation coefficients (CCC) between the relative abundances of the most abundant pollen types obtained for Silicone and Vaseline by HTS analysis.

\begin{tabular}{lllll}
\hline Pollen type & Total & Week 1 & Week 2 & Week 3 \\
\hline Cupressaceae & 0.92 & 0.90 & 0.94 & 0.95 \\
Olea & 0.91 & 0.99 & 0.98 & 0.88 \\
Pinus & 0.67 & 0.84 & $N A$ & 0.66 \\
Platanus & 0.99 & $N A$ & 0.99 & $N A$ \\
Poaceae & 0.92 & 0.92 & $N A$ & 0.89 \\
Quercus & 0.96 & 0.91 & $N A$ & 0.96 \\
\hline
\end{tabular}

$N A$ : Relative abundance $<2 \%$ or insufficient observations for the analysis.

pollen concentrations registered by one adhesive is always higher than the concentrations registered by the other. This is the case of Pinus pollen for the daily analysis (discussed below).

Other similar experiences have shown an acceptable global corre spondence between Silicone (independent on the solvent employed) and Vaseline (Comtois and Mandrioli, 1997; Galán and Domínguez Vilches, 1997; Maya Manzano et al., 2018), although occasionally they have exposed significant differences. Therefore, we believe that some other aspects must be taken into account for evaluating the impaction efficiency of the adhesives such as: i) differences regarding to the abundance of the pollen types; ii) divergences on time scales studies; and iii) the effect of environmental conditions, particularly when out door samples are analyzed.

When the analyses were performed based on the abundance of the pollen types, the greatest divergences were noted for the less abundant pollen types during this period, e.g. Apiaceae, Cyperaceae, Compositae, although CCC value from the absolute pollen concentrations was also higher than 0.90 . This topic has previously been considered by Comtois et al. (1999) and Šikoparija et al. (2011, 2017), observing an increase of the error in the measurements when the number of counted pollen is low, fact also analyzed by Cotos Yáñez et al. (2013) who concluded that the variations in low pollen concentrations are related to the analysis of only a fraction of the sample because pollen grains, specially the less abundant, are irregularly distributed on the slide. Noticing this bias, we focused on the main pollen types based on the pollen abundance in the atmosphere: Cupressaceae, Olea, Pinus, Platanus, Poaceae and Quercus. Nonetheless, these pollen types represented the $87 \%$ of the total pollen counts in this study and approximately $7080 \%$ of the total annual pollen amounts in central Spain (Pérez Badia et al., 2010, 2011; Rojo et al., 2016), including the most relevant allergenic pollen types in the atmosphere of the Mediterranean region (D'Amato et al., 2007): Poa ceae, Olea, Cupressaceae or Platanus. The greatest divergence observed in our study was found in Pinus pollen for both morphological and molecular analyses, with $\sim 25 \%$ higher daily collection in Silicone compared with Vaseline. Aerosol capture depends mostly on two fea tures: adhesiveness properties of the collection surface and physical characteristics (density and size) of the particles (Hinds, 1982). Ac cordingly, Razmovski et al. (1998) concluded that the ornamentation of the pollen influences on the capturing efficiency testing different ad hesives. Pinus pollen is vesiculate and much larger than the rest of the pollen type studied, so it is likely that the differences in adhesiveness between Silicone and Vaseline arise especially for this particular pollen type, although controlled studies would be required to clarify this hy pothesis.

Differences between adhesives became more evident when the data were analyzed hourly compared to other larger time scale (daily or total). Maya Manzano et al. (2018) compared the intradiurnal pattern of the pollen concentrations between Silicone (prepared with carbon tetrachloride) and Vaseline, observing similar patterns in both ad hesives but great variability between them. In our opinion, the pollen variations observed in the hourly time scale are again attributable to an adhesive independent error because Tormo Molina et al. (2013) in dicated similar results when two independent devices with the same adhesive were compared. The comparisons at intradiurnal time scale requires more detailed procedures, e.g. a greater number of days with high pollen concentrations should be considered.

Finally, meteorological conditions may affect the adhesiveness properties of the adhesives as stated by Käpylä (1989). Silicone is a very stable adhesive to weather conditions while the physical properties of 

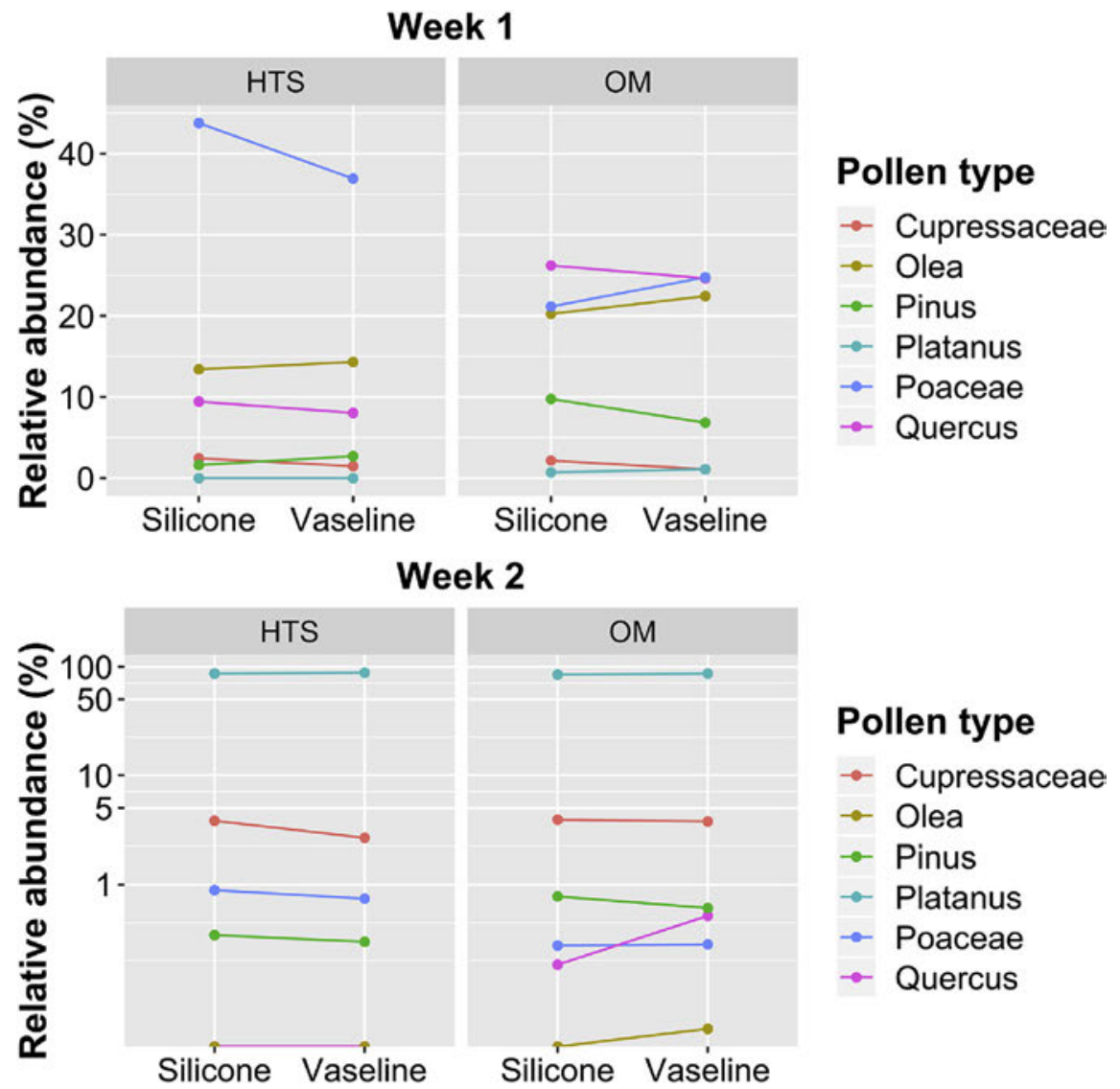

\section{Pollen type}

$\rightarrow$ Cupressaceae

$\rightarrow$ Olea

$\rightarrow$ Pinus

$\rightarrow$ Platanus

- Poaceae

$\rightarrow$ Quercus

Week 3
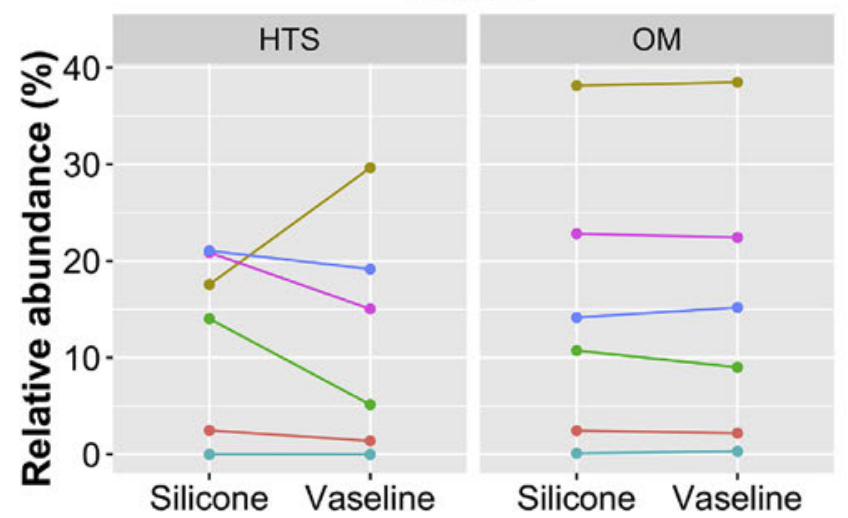

\section{Pollen type}

$\rightarrow$ Cupressaceae

$\rightarrow$ Olea

$\rightarrow$ Pinus

- Platanus

- Poaceae

$\rightarrow$ Quercus

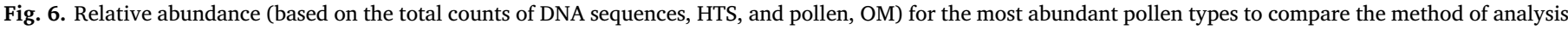

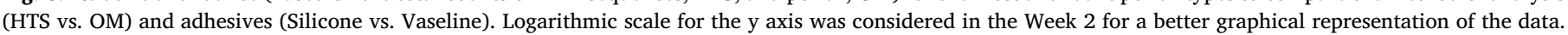

the Vaseline such as its viscosity and adhesiveness are mainly influ enced by temperature (Käpylä, 1989). Thus, the high temperatures reached in the warmest areas of the Mediterranean region can influence the viscosity and the thickness of the film of Vaseline on the tape. Ac cording to Comtois and Mandrioli (1997), and Galán and Domínguez Vilches (1997), temperatures exceeding the level of $3045^{\circ} \mathrm{C}$ can alter Vaseline stability. On the other hand, Käpylä (1989) described a de crease on the impaction efficiency for Vaseline below $20^{\circ} \mathrm{C}$, although it has not been supported by other studies conducted in outdoor condi tions (Galán and Domínguez Vilches, 1997). Our results from mor phological and molecular analyses did not show significant differences between the Silicone and Vaseline regarding the capturing behavior despite the fact that the samples were collected at different seasons, including temperatures that ranged from $1{ }^{\circ} \mathrm{C}$ (February 2017) to $35.8^{\circ} \mathrm{C}$ (June 2016), which suggests that the collection is not affected by the potential changes in the properties of the adhesives. Moreover, the periods analyzed (February June) approximately includes $90 \%$ of the total amount of pollen (Pérez Badia et al., 2010; Rojo et al., 2016), which constitutes a remarked representation of the largest amounts of pollen recorded during the annual pollen season.

In addition, our study not only evaluated the influence of the ad hesives but also the divergences attending to the analysis approach (OM vs. HTS). Although most pollen types were concomitantly detected by both methods, the concordance of the relative abundances was de pendent on the total diversity of pollen types present in the air. Thus, samples collected during spring and summer (June 2016 and May 2017), when pollen diversity increases, showed low CCC values, while for March 2017, when Platanus pollen is predominant, retrieved ex cellent concordance (CCC $=1.00$ for both adhesives). However, part of these differences may be caused by inherent features of the techniques 
Table 4

Concordance correlation coefficients (CCC) between the relative abundances of the pollen types to compare the different analysis method (Optical microscopy = OM vs. High-Throughput Sequencing = HTS) and different adhesive substance (Silicone $=$ Sil vs. Vaseline $=$ Vas).

\begin{tabular}{llll}
\hline Week & Analysis & Adhesive & CCC \\
\hline Week 1 & OM & Sil vs. Vas & 0.99 \\
& HTS & Sil vs. Vas & 0.98 \\
& OM vs. HTS & Sil & 0.70 \\
Week 2 & OM vs. HTS & Vas & 0.78 \\
& OM & Sil vs. Vas & 1.00 \\
& HTS & Sil vs. Vas & 1.00 \\
Week 3 & OM vs. HTS & Sil & 1.00 \\
& OM vs. HTS & Vas & 1.00 \\
& OM & Sil vs. Vas & 1.00 \\
& HTS & Sil vs. Vas & 0.90 \\
& OM vs. HTS & Sil & 0.81 \\
& OM vs. HTS & Vas & 0.92 \\
\hline
\end{tabular}

and the sampling procedure. For instance, OM measures pollen con centrations in the air while HTS analyzes DNA of a selected region of the plant genome present in the pollen grains but also other plant re sidues that can be in the sample. This also implies that comparisons must be performed using relative abundances. Moreover, the number of copies of the amplified ITS region can vary from one plant species to another, so the comparison between both methodologies may not be straightforward and specific corrections would be required. Additionally, HTS employed the whole tape for the analysis while OM procedure is based on statistical estimation from a subsample of the tape (Cariñanos et al., 2000; Cotos Yáñez et al., 2013; Gharbi et al., 2017; Tormo Molina et al., 1996). Furthermore, the collection for OM and HTS were performed using different pollen traps running syn chronically, fact that implies assuming certain instrumental error (Tormo Molina et al., 2013). Although comparisons may be hampered for these reasons and further studies should address these issues, the results using data from the same technique were consistent and pointing the same conclusion, that both adhesives retrieve comparable outcomes.

Either way, both analysis techniques, OM and HTS, can be com plementary because they provide very useful information about the biotic content of the atmosphere (Clauß, 2015; Mullins and Emberlin, 1997; Núñez et al., 2016a, 2016b). HTS offers better taxonomic re solution, solving the uncertainty of some pollen types like Poaceae, Cupressaceae or Chenopodiaceae/Amaranthaceae, and retrieving, in most cases, a taxonomic identification at Genus level. This fact pro motes the implementation of this technology in aerobiology (Bell et al., 2016; Korpelainen and Pietiläinen, 2017; Kraaijeveld et al., 2015). On the other hand, although extremely time consuming and considerable expertise required, one essential point to keep using morphologic identification is the quantification of the grains from the different pollen types with a more detailed time resolution, which cannot be currently inferred from our HTS approach. The pollen concentrations are currently employed to provide public alerts about allergenic pollen in the atmosphere. One strategy to take advantage of the benefits of both approaches, DNA sequencing and microscopy, would be to com bine the pollen identification by HTS and the quantification of the total count of pollen from microscopy to infer the alerts for allergenic pollen types, although more studies relating both analyses should be con ducted (Gutiérrez Bustillo et al., 2016).

\section{Conclusions}

The comparison of the pollen concentrations between both ad hesives, Silicone prepared with cyclohexane and Vaseline, under non controlled conditions showed a high degree of agreement. This con cordance was tested by two different methods: morphological analysis by optical microscopy (OM, the most accepted methodology in aero palynology), and molecular analysis based on high throughput DNA sequencing (HTS). Among all the pollen types analyzed, only relevant differences were observed for Pinus, with an assumable deviation of higher pollen concentrations detected in Silicone compared to Vaseline. Based on our results, these two adhesives can be used indistinctly, and daily pollen records derived from them are comparable data. Moreover, they are both appropriate for avoiding the negative effects of Volatile Organic Compounds (VOCs) like carbon tetrachloride, classified as potential human carcinogen and still used in the formulation of some adhesives in aerobiology.

\section{Acknowledgments}

This study was funded by the Community of Madrid (Spain), under the AIRBIOTA CM Program (S2013/MAE 2874). The authors thank the Castilla La Mancha Government, the European Social Fund (FSE) and the Youth Employment Initiative (YEI) for the predoctoral grant of B.L and the University of Castilla La Mancha for its support with the "Plan Propio de $\mathrm{I}+\mathrm{D}+\mathrm{I}$ ". B.S P acknowledges the post doctoral grant co funded by the European Social Fund through the Youth Employment Operative Program and the Youth Employment Initiative (YEI). Finally, we are grateful to the anonymous reviewers for their comments in a previous version of this paper.

\section{Appendix A. Supplementary data}

Supplementary data to this article can be found online at https:// doi.org/10.1016/j.jenvman.2019.03.116.

\section{References}

Alcázar, P., Comtois, P., 1999. A new adhesive for airborne pollen sampling. Aerobiologia 15, 105-108. https://doi.org/10.1023/A:1007505517863.

Alcázar, P., Galán, C., Cariñanos, P., Domínguez-Vilches, E., 2003. A new adhesive for airborne pollen sampling in Spain. Aerobiologia 19, 57-61. https://doi.org/10.1023/ A:1022692228699.

Aylor, D.E., 1993. Relative collection efficiency of Rotorod and Burkard spore samplers for airborne Venturia inaequalis ascospores. Phytopathology 83, 1116-1119. https:// doi.org/10.1094/Phyto-83-1116.

Bell, K.L., de Vere, N., Keller, A., Richardson, R.T., Gous, A., Burgess, K.S., Brosi, B.J., 2016. Pollen DNA barcoding: current applications and future prospects. Genome 59, 629-640. https://doi.org/10.1139/gen-2015-0200.

Bonofiglio, T., Orlandi, F., Ruga, L., Romano, B., Fornaciari, M., 2013. Climate change impact on the olive pollen season in Mediterranean areas of Italy: air quality in late spring from an allergenic point of view. Environ. Monit. Assess. 185, 877-890. https://doi.org/10.1007/s10661-012-2598-9.

Caporaso, J.G., Kuczynski, J., Stombaugh, J., Bittinger, K., Bushman, F.D., Costello, E.K., Fierer, N., González Peña, A., Goodrich, J.K., Gordon, J.I., Huttley, G.A., Kelley, S.T., Knights, D., Koenig, J.E., Ley, R.E., Lozupone, C.A., McDonald, D., Muegge, B.D., Pirrung, M., Reeder, J., Sevinsky, J.R., Tumbaugh, P.J., Walters, W.A., Widmann, J., Yatsunenko, T., Zaneveld, J., Knight, R., 2010. QIIME allows analysis of highthroughput community sequencing data. Nat. Methods 7, 335-336. https://doi.org/ 10.1038/nmeth.f.303.

Cariñanos, P., Emberlin, J., Galán, C., Dominguez-Vilches, E., 2000. Comparison of two pollen counting methods of slides from a Hirst type volumetric trap. Aerobiologia 16 339-346. https://doi.org/10.1023/A:1026577406912.

CEN/TS 16868, 2017. Ambient Air. Sampling and Analysis of Airborne Pollen Grains and Fungal Spores for Networks Related to Allergy. Volumetric Hirst method.

Cheng, T., Xu, C., Lei, L., Li, C.H., Zhang, Y., Zhou, S.L., 2016. Barcoding the kingdom Plantae: new PCR primers for ITS regions of plants with improved universality and specificity. Mol. Ecol. Resour. 16, 138-149. https://doi.org/10.1111/1755-0998. 12438.

Clauß, M., 2015. Particle size distribution of airborne microorganisms in the environment - a review. Landbauforsch. Appl. Agric. For. Res. 65, 77-99. https://literatur.thuenen. de/digbib extern/dn055711.pdf.

Comtois, P., Alcazar, P., Néron, D., 1999. Pollen counts statistics and its relevance to precision. Aerobiologia 15, 19-28. https://doi.org/10.1023/A:1007501017470.

Comtois, P., Mandrioli, P., 1997. Pollen capture media: a comparative study. Aerobiologia 13, 149-154. https://doi.org/10.1007/BF02694501.

Cotos-Yáñez, T.R., Rodríguez-Rajo, F.J., Pérez-González, A., Aira, M.J., Jato, V., 2013 Quality control in aerobiology: comparison different slide reading methods. Aerobiologia 29, 1-11. https://doi.org/10.1007/s10453-012-9263-1.

D'Amato, G., Cecchi, L., Bonini, S., Nunes, C., Annesi-Maesano, I., Behrendt, H., Liccardi, G., Popov, T., Van Cauwenberge, P., 2007. Allergenic pollen and pollen allergy in Europe. Allergy 62, 976-990. https://doi.org/10.1111/j.1398-9995.2007.01393.x.

Fröhlich-Nowoisky, J., Kampf, C.J., Weber, B., Huffman, J.A., Pöhlker, C., Andreae, M.O., Lang-Yona, N., Burrows, S.M., Gunthe, S.S., Elbert, W., Su, H., Hoor, P., Thines, E., 
Hoffmann, T., Després, V.R., Pöschl, U., 2016. Bioaerosols in the Earth system: climate, health, and ecosystem interactions. Atmos. Res. 182, 346-376. https://doi.org/ 10.1016/j.atmosres.2016.07.018.

Furuse, M., Kanno, S., Takano, T., Matsumura, Y., 2001. Cyclohexane as an alternative vapor of carbon tetrachloride for the assessment of gas removing capacities of gas masks. Ind. Health 39, 1-7. https://doi.org/10.2486/indhealth.39.1.

Galán, C., Cariñanos, P., Alcázar, P., Domínguez-Vilches, E., 2007. Spanish Aerobiology Network (REA): Management and Quality Manual. Servicio de Publicaciones de la Universidad de Córdoba, Spain. www.uco.es/rea/infor rea/manual eng.pdf.

Galán, C., Domínguez-Vilches, E., 1997. The capture media in aerobiological sampling. Aerobiologia 13, 155-160. https://doi.org/10.1007/BF02694502.

Galán, C., Smith, M., Thibaudon, M., Frenguelli, G., Oteros, J., Gehrig, R., Berger, U., Clot, B., Brandao, R., EAS QC Working Group, 2014. Pollen monitoring: minimum requirements and reproducibility of analysis. Aerobiologia 30, 385-395. https://doi. org/10.1007/s10453-014-9335-5.

García-Mozo, H., 2011. The use of aerobiological data on agronomical studies. Ann. Agric. Environ. Med. 18, 1-6. www.aaem.pl/Issue-1-2011,2526.

Gharbi, D., Brighetti, M.A., Travaglini, A., Trigo, M.M., 2017. Comparison between the counting methods used by two aerobiology networks in southern Europe (Spain and Italy). Aerobiologia 33, 87-92. https://doi.org/10.1007/s10453-016-9452-4.

Gharbi, D., Trigo, M.M., Recio, M., 2019. The use of cyclohexane as new solvent for airborne pollen sampling. Aerobiologia. https://doi.org/10.1007/s10453-01909568-0.

Gutiérrez-Bustillo, A.M., Ferencova, Z., Núñez, A., Alcamí, A., Campoy, P., Guantes, R., Moreno, D.A., 2016. Análisis por técnicas morfológicas y secuenciación de ADN del polen atmosférico de la Comunidad de Madrid: estudios preliminaries. Rev. Salud Anim. 16, 71-77. [in Spanish]. www.ojs.diffundit.com/index.php/rsa/article/view/ $804 / 758$.

Hinds, W.C., 1982. Aerosol Technology: Properties, Behavior, and Measurement of Airborne Particles, second ed. John Wiley and Sons, New York.

Hirst, J.M., 1952. An automatic volumetric spore trap. Ann. Appl. Biol. 39, 257-265. https://doi.org/10.1111/j.1744-7348.1952.tb00904.x.

Hogan, A.W., 1971. Evaluation of a silicone adhesive as an aerosol collecting medium. J. Appl. Meteorol. 10, 592-595. https://journals.ametsoc.org/doi/pdf/10.1175/15200450\%281971\%29010\%3C0592\%3AEOASAA\%3E2.0.CO $\% 3 B 2$.

Jäger, S., Mandrioli, P., Spieksma, F., Emberlin, J., Hjelmroos, M., Rantio-Lehtimäki, A., Domínguez-Vilches, E., Ickovic, M.-R., 1995. Methodology for routinely performed monitoring of airborne pollen recommendations. Aerobiologia 11, 69. https://doi. org /10.1007/BF02136148.

Käpylä, M., 1989. Adhesives and mounting media in aerobiological sampling. Grana 28, 215-218. https://doi.org/10.1080/00173138909427434.

Korpelainen, H., Pietiläinen, M., 2017. Biodiversity of pollen in indoor air samples as revealed by DNA metabarcoding. Nord. J. Bot., Le 35, 602-608. https://doi.org/10. $1111 /$ njb.01623.

Kraaijeveld, K., de Weger, L.A., Ventayol García, M., Buermans, H., Frank, J., Hiemstra, P.S., den Dunnen, J.T., 2015. Efficient and sensitive identification and quantification of airborne pollen using next-generation DNA sequencing. Mol. Ecol. Resour. 15, 8-16. https://doi.org/10.1111/1755-0998.12288.

Leontidou, K., Vernesi, C., De Groeve, J., Cristofolini, F., Vokou, D., Cristofori, A., 2018. DNA metabarcoding of airborne pollen: new protocols for improved taxonomic identification of environmental samples. Aerobiologia 34, 63-74. https://doi.org/10. 1007/s10453-017-9497-z.

Levetin, E., Rogers, C.A., Hall, S.A., 2000. Comparison of pollen sampling with a Burkard spore trap and a Tauber trap in a warm temperate climate. Grana 39, 294-302. https://doi.org/10.1080/00173130052504333.

Lin, L.I.-K., 1989. A concordance correlation coefficient to evaluate reproducibility. Biometrics 45, 255-268. https://doi.org/10.2307/2532051.

Manibusan, M.K., Odin, M., Eastmond, D.A., 2007. Postulated carbon tetrachloride mode of action: a review. J. Environ. Sci. Health C Environ. Carcinog. Ecotoxicol. Rev. 25, 185-209. https://doi.org/10.1080/10590500701569398.

Marchetti, P., Pesce, G., Villani, S., Antonicelli, L., Ariano, R., Attena, F., Bono, R., Bellisario, V., Fois, A., Gibelli, N., Nicolis, M., Olivieri, M., Pirina, P., Scopano, E., Siniscalco, C., Verlato, G., Marcon, A., 2017. Pollen concentrations and prevalence of asthma and allergic rhinitis in Italy: Evidence from the GEIRD study. Sci. Total Environ. 584 (585), 1093-1099. https://doi.org/10.1016/j.scitotenv.2017.01.168.

Masella, A.P., Bartram, A.K., Truszkowski, J.M., Brown, D.G., Neufeld, J.D., 2012 PANDAseq: paired-end assembler for illumina sequences. BMC Bioinf. 13, 31. https:// doi.org/10.1186/1471-2105-13-31.

Maya-Manzano, J.M., Fernández-Rodríguez, S., Silva-Palacios, I., Gonzalo-Garijo, A., Tormo-Molina, R., 2018. Comparison between two adhesives (silicone and petroleum jelly) in Hirst pollen traps in a controlled environment. Grana 57, 137-143. https:// doi.org/10.1080/00173134.2017.1319973.

McBride, G.B., 2005. A Proposal for Strength-Of-Agreement Criteria for Lin's Concordance Correlation Coefficient. National Institute of Water \& Atmospheric Research Ltd. New Zealand.

McMurdie, P.J., Holmes, S., 2013. phyloseq: an R package for reproducible interactive analysis and graphics of microbiome census data. PLoS One 8, e61217. https://doi. org/10.1371/journal.pone.0061217.

Mullins, J., Emberlin, J., 1997. Sampling pollens. J. Aerosol Sci. 28, 365-370. https://doi. org/10.1016/S0021-8502(96)00439-9.

Núñez, A., Amo de Paz, G., Ferencova, Z., Rastrojo, A., Guantes, R., García, A.M., Alcamí, A., Gutiérrez-Bustillo, A.M., Moreno, D.A., 2017. Validation of the Hirst-type spore trap for simultaneous monitoring of prokaryotic and eukaryotic biodiversities in urban air samples by next-generation sequencing. Appl. Environ. Microbiol. 83, e00472-17. https://doi.org/10.1128/AEM.00472-17.

Núñez, A., Amo de Paz, G., Rastrojo, A., García, A.M., Alcamí, A., Gutiérrez-Bustillo, A.M.,
Moreno, D.A., 2016a. Monitoring of airborne biological particles in outdoor atmosphere. Part 1: Importance, variability and ratios. Int. Microbiol. 19, 1-13. https:// doi.org/10.2436/20.1501.01.258.

Núñez, A., Amo de Paz, G., Rastrojo, A., García, A.M., Alcamí, A., Gutiérrez-Bustillo, A.M., Moreno, D.A., 2016b. Monitoring of airborne biological particles in outdoor atmosphere. Part 2: Metagenomics applied to urban environments. Int. Microbiol. 19, 69-80. https://doi.org/10.2436/20.1501.01.265.

Oteros, J., Buters, J., Laven, G., Röseler, S., Wachter, R., Schmidt-Weber, C., Hofmann, F., 2017. Errors in determining the flow rate of Hirst-type pollen traps. Aerobiologia 33, 201-210. https://doi.org/10.1007/s10453-016-9467-x.

Oteros, J., Galán, C., Alcázar, P., Domínguez-Vilches, E., 2013. Quality control in biomonitoring networks, Spanish Aerobiology Network. Sci. Total Environ. 443 559-565. https://doi.org/10.1016/j.scitotenv.2012.11.040.

Oteros, J., García-Mozo, H., Alcázar, P., Belmonte, J., Bermejo, D., Boi, M., Cariñanos, P., Díaz de la Guardia, C., Fernández-González, D., González-Minero, F., GutiérrezBustillo, A.M., Moreno-Grau, S., Pérez-Badia, R., Rodríguez-Rajo, F.J., RuízValenzuela, L., Suárez-Pérez, J., Trigo, M.M., Domínguez-Vilches, E., Galán, C., 2015. A new method for determining the sources of airborne particles. J. Environ. Manag. 155, 212-218. https://doi.org/10.1016/j.jenvman.2015.03.037.

Paulson, J.N., Stine, O.C., Bravo, H.C., Pop, M., 2013. Differential abundance analysis for microbial marker-gene surveys. Nat. Methods 10, 1200-1202. https://doi.org/10. 1038/nmeth.2658.

Pérez-Badia, R., Rapp, A., Morales, C., Sardinero, S., Galán, C., García-Mozo, H., 2010. Pollen spectrum and risk of pollen allergy in central Spain. Ann. Agric. Environ. Med. 17, 139-151. www.aaem.pl/Pollen-spectrum-and-risk-of-pollen-allergy-in-centralSpain-,71626,0,2.html.

Pérez-Badia, R., Rapp, A., Vaquero, C., Fernández-González, F., 2011. Aerobiological study in east-central Iberian Peninsula: pollen diversity and dynamics for major taxa. Ann. Agric. Environ. Med. 18, 99-111. www.aaem.pl/Aerobiological-study-in-eastcentral-Iberian-Peninsula-pollen-diversity-and-dynamics-for-major-taxa-,71669,0,2. html.

Pohanish, R.P., 2017. Sittig's Handbook of Toxic and Hazardous Chemicals and Carcinogens, seventh ed. Elsevier.

R Development Core Team, 2017. R: A Language and Environment for Statistical Computing. The R Foundation for Statistical Computing, Vienna, Austria. http:// www.R-project.org/, Accessed date: 12 January 2018.

Razmovski, V., O'Meara, T., Hjelmroos, M., Marks, G., Tovey, E., 1998. Adhesive tapes as capturing surfaces in Burkard sampling. Grana 37, 305-310. https://doi.org/10. $1080 / 00173139809362683$

Rojo, J., Rapp, A., Lara, B., Sabariego, S., Fernández-González, F., Pérez-Badia, R., 2016. Characterisation of the airborne pollen spectrum in Guadalajara (central Spain) and estimation of the potential allergy risk. Environ. Monit. Assess. 188, 130. https://doi. org/10.1007/s10661-016-5129-2.

Šikoparija, B., Galán, C., Smith, M., EAS QC Working Group, 2017. Pollen-monitoring: between analyst proficiency testing. Aerobiologia 33, 191-199. https://doi.org/10. 1007/s10453-016-9461-3.

Šikoparija, B., Pejak-Šikoparija, T., Radišić, P., Smith, M., Galán, C., 2011. The effect of changes to the method of estimating the pollen count from aerobiological samples. J. Environ. Monit. 13, 384-390. https://doi.org/10.1039/C0EM00335B.

Stevenson, M., Nunes, T., Heuer, C., Marshall, J., Sanchez, J., Thornton, R., Reiczigel, J., Robison-Cox, J., Sebastiani, P., Solymos, P., Yoshida, K., Jones, G., Pirikahu, S., Firestone, S., Kyle, R., Popp, J., Jay, M., 2017. epiR: Tools for the Analysis of Epidemiological Data. R package version 09-96. https://CRAN.R-project.org/ package = epiR, Accessed date: 10 March 2018 .

Thibaudon, M., Galán, C., Lanzoni, C., Monnier, S., 2015. Validation of a new adhesive coating solution: comparative study of carbon tetrachloride and diethyl ether. Aerobiologia 31, 57-62. https://doi.org/10.1007/s10453-014-9346-2.

Tormo-Molina, R., Maya-Manzano, J.M., Fernández-Rodríguez, S., Gonzalo-Garijo, A., Silva-Palacios, I., 2013. Influence of environmental factors on measurements with Hirst spore traps. Grana 52, 59-70. https://doi.org/10.1080/00173134.2012. 718359.

Tormo-Molina, R., Muñoz-Rodríguez, A., Silva-Palacios, I., 1996. Sampling in aerobiology. Differences between traverses along the length of the slide in Hirst spore traps. Aerobiologia 12, 161-166. https://doi.org/10.1007/BF02447407.

UNI, (Ente Italiano di Normazione) 11108, 2004. Qualità dell'Aria: Metodo di campionamento e conteggio dei granuli pollinici e delle spore fungine aerodisperse. http:// store.uni.com/catalogo/index.php/uni-11108-2004.html.

Warner, F.E., McCartney, H.A., Emberlin, J., 2000. Wind tunnel comparison of the collection efficiency of three Hirst-type volumetric sampler drum coatings. Aerobiologia 16, 25-28. https://doi.org/10.1023/A:1007637105259.

White, T.J., Bruns, T., Lee, S., Taylor, J., 1990. Amplification and direct sequencing of fungal ribosomal RNA genes for phylogenetics. In: Innis, M.A., Gelfand, D.H., Shinsky, J.J., White, T.J. (Eds.), PCR Protocols: A Guide to Methods and Applications. Academic Press, Inc., New York, pp. 315-322. https://doi.org/10.1016/B978-0-12372180-8.50042-1.

Willis, M.R., Keller, A.A., 2007. A framework for assessing the impact of land use policy on community exposure to air toxics. J. Environ. Manag. 83, 213-227. https://doi. org/10.1016/j.jenvman.2006.03.011.

Ziello, C., Sparks, T.H., Estrella, N., Belmonte, J., Bergmann, K.C., Bucher, E., Brighetti, M.A., Damialis, A., Detandt, M., Galán, C., Gehrig, R., Grewling, L., GutiérrezBustillo, A.M., Hallsdóttir, M., Kockhans-Bieda, M.-C., De Linares, C., Myszkowska, D., Pàldy, A., Sánchez, A., Smith, M., Thibaudon, M., Travaglini, A., Uruska, A., Valencia-Barrera, R.M., Vokou, D., Wachter, R., de Weger, L.A., Menzel, A., 2012. Changes to airborne pollen counts across Europe. PLoS One 7 (4), e34076. https:// doi.org/10.1371/journal.pone.0034076. 